\title{
CAFFEIC ACID METABOLISM BY ABSIDIA CORYMBIFERA
}

\author{
Mohammed Hosny ${ }^{1}$; Zeinab Abdel-Aziz ${ }^{2}$; Mahmoud M. El-aasser ${ }^{3}$; and Monira Zhran ${ }^{2}$ \\ ${ }^{\mathbf{1}}$ Department of Pharmacognosy, Faculty of Pharmacy, Al-Azhar University, Cairo, Egypt. \\ ${ }^{2}$ Department of Microbiology, Faculty of Science (Girls), Al-Azhar University, Cairo, Egypt. \\ ${ }^{3}$ Regional Center of Mycology, Al-Azhar University, Cairo, Egypt.
}

\begin{abstract}
Biocatalytic processes may offer a cheaper alternative to natural production of valuable compounds. Caffeic acid [3,4-dihydroxycinnamic acid] (1) metabolism was studied using for the first time the fungus Absidia corymbiferaa cosmopolitan filamentous phytopathogenic fungus as a biocatalyst. Results show that caffeic acid is converted to Ferulic acid [Caff-AM-1], 3,4-dimethoxy-cinnamic acid[Caff-AM-2] and 4-hydroxycinnamyl alcohol [Caff-AM-3]. The structures of the metabolic products were elucidated on the basis of their spectral data. A possible metabolic pathway of the biotransformation and the antioxidant activity using DPPH radical scavenging assay and lipid peroxidation assay by thiobarbituric acid reactive substances (TBARS) method using rat tissue homogenates is also discussed.
\end{abstract}

Key words: Biotransformation, caffeic acid, Absidia corymbifera, metabolic pathway, antioxidant activity.

\section{INTRODUCTION}

Biocatalysis or biotransformation encompasses the use of biological systems to catalyze the conversion of one compound to another. The catalyst part can thereby consist of wholecells, cellular extracts, or isolated enzyme (s). If the conversion is developed by a free and/or immobilized enzyme, it means biocatalysts, but if these transformations take place by the wholecell (with the correct enzyme) we talk about biotransformation (Leresche and Meyer, 2006). Although the currentinterest in applying biotransformation in organic synthesis is mainly related to the preparation of enantiopure compounds, these can also use to perform transformations of chiral functional groups. The reason is that biotransformations are carried out usually at room temperature and atmospheric pressure, avoiding the use of extreme reaction conditions, and minimizing problems of isomerization, racemization, epimerization or transposition (Luna, 2004). Therefore, biotransformations attract considerable attention due to its simple, cheap and benign methodologies that combines green chemistry with high efficiency (Faber and Patel, 2000). Besides, biotransformation experiments using phytopathogenic fungi provide information on the detoxification mechanism used by these microorganisms and give an indication of the structural modifications that may be necessary if substrates of this type are to be further developed as selective fungal control agents (Daoubi et al., 2005).

On the other hand, cinnamic acid derivatives such as caffeic acid (3,4dihydroxycinnamic acid) can potentially serve as a good source of starting material for the production of value-added compounds. Several studies have demonstrated that valuable aroma, flavoring compounds, and pharmaceutical intermediates, are produced as intermediates in the degradation pathways of such cinnamic acid derivatives (Velasco et al., 2010). Thus, biotransformation of these compounds seems to be a reasonable alternative to produce raw materials for different industries. Also, products of such bioconversions are 
considered natural (Shimoni et al., 2000), which gives them better perspectives of use than synthetic counterparts.

Caffeic acid (3,4-dihydroxycinnamic acid) is a phenolic compound widely distributed in medicinal plants, including fruits, vegetables, wine, coffee and olive oil, among others, and is therefore present in human plasma in a diet dependent concentration (Miles $\boldsymbol{e t}$ al., 2005). Caffeic acid possesses a wide spectrum of biological activities, e.g. anti-cancer, anti-oxidant, anti-angiogenic, anti-inflammatory antinociceptive, anti-hyperglycemic and hepato-protective properties (Gulçin, 2006; Mateos et al., 2006; Un-Ju et al., 2006; Jung et al., (2007; Jeong Hun et al., 2009; Soo-Hyun et al., 2011). Based on the anti-oxidant and anti-angiogenic effects of caffeic acid, retinal neovascularization of retinopathy of prematurity could be a target for the pharmacological application of caffeic acid. Microbial transformations of caffeic acid by bacteria and fungi conducted so far have focused largely on the identification of metabolic pathways and routes of degradation (Whiting and Carr, 1959; Samejima $\boldsymbol{e t}$ al., 1987; Robert et al., 1988; Defnoun et al., 2000; Toshiki et al., 2012). Caffeic acid is sequentially degraded to Protocatechuic acid, 4-vinylcatechol, vanillyl alcohol, vanillic acid, dihydro-caffeic acid, 4-ethylcatechol, m-hydroxy-phenylpropionic acid and 3,4dihydroxyphenylpropionic acid by bacteria and fungi (Whiting and Carr, 1959; Samejima et al., 1987; Robert et al., 1988; Defnoun et al., 2000; Toshiki et al., 2012). This paper reports for the first time the capability of the fungus Absidia corymbifera, a cosmopolitan filamentous phytopathogenic fungus to biotransform caffeic acid into value-added products. A possible metabolic pathway of the biotransformation and the antioxidant activity is also discussed.

\section{EXPERIMENTAL SECTION}

\section{General Experimental Procedures:}

Infra-red spectra were recorded using a Bruker Tensor 27 FT-IR (BrukerOpticsGmbH, Ettlingen, Germany) spectrometer with $\mathrm{KBr}$ pellets and UV spectra were determined JASCO V-520 UV/VIS spectrophotometer. JEOL NMR spectrometer operating at $500 \mathrm{MHz}$ for ${ }^{1} \mathrm{H}-\mathrm{NMR}$ spectra were obtained in CDOD or $\mathrm{CDCl}_{3}$ usingTMS as an internal standard with the chemical shifts expressed in $\delta$ and coupling constants $(J)$ in Hertz. El-MS (VG-ZAB-H F), X-mass (158.64, 800.00) (VGA analytical, Inc.).Silicagel column chromatography (CC) was performed on silica gel 60 (E. Merck, Darmstadt, Germany). TLC was carried out on precoated silica gel $60 \mathrm{~F}_{254}$ (Merck) plates. Developed chromatograms were visualized by spray with $1 \%$ vanillin $/ \mathrm{H}_{2} \mathrm{SO}_{4}$, followed by heating at $100^{\circ} \mathrm{C}$ for 3 min. TLC plates were developed with solvent systems: A (EtOAc:Hexane, 1:1, v:v) or B $\left(\mathrm{CHCl}_{3}: \mathrm{MeOH}, 8.5: 1.5\right.$, v:v). Caffeic acid (1), used in this study was given as a gift from Prof. Mohammed Hosny, Al-Azhar University, Faculty of Pharmacy, Pharmacognosy Department, Cairo, Egypt. The purity of the substrates was confirmed by TLC and ${ }^{1} \mathrm{H}-\mathrm{NMR}$.

\section{Microorganisms:}

Cunninghamella elegans (RCMB 012001), Cunninghamella echinulata (RCMB 012002), Mucorrouxii (RCMB 015004), Absidia corymbifera (RCMB 051002), Penicillium notatum (RCMB 001023), Penicillium aurantiogriseum (RCMB), Candida albicans (RCMB 005004), Rhodotorula glutins (RCMB 028001), Rhizopus oryzae (RCMB 014002), Aspergillus niger (RCMB002007(5)001002(2) and Aspergillus flavus RCMB002002(3)were obtained from Mycology and Biotechnology Center, Al-Azhar University, Cairo, Egypt. 


\section{Analytical-Scale Biotransformation of Caffeic acid(1):}

A two-stage fermentation protocol (Hosny and John (1999)), was used for analytical and preparative scale formation of (1) metabolites. For screening experiments, solid cultures kept on either potato dextrose agar or sabaraud maltose agar of the following organisms was used: Cunninghamella elegans (RCMB 012001), Cunninghamella echinulata (RCMB 012002), Mucorrouxii (RCMB 015004), Absidia corymbifera (RCMB 051002), Penicillium notatum (RCMB 001023), Penicillium aurantiogriseum (RCMB), Candida albicans (RCMB 005004), Rhodotorula glutins (RCMB 028001), Rhizopus oryzae (RCMB 014002), Aspergillus niger (RCMB002007(5)001002(2) and Aspergillus flavus RCMB002002(3). Each culture was used separately to inoculate $100 \mathrm{ml}$ flasks containing one fifth of their volume of the following medium: $5 \%(\mathrm{w} / \mathrm{v})$ soybean meal, $0.5 \%$ yeast extract, $0.5 \% \mathrm{NaCl}$, $0.5 \% \mathrm{~K}_{2} \mathrm{HPO}_{4}$, and $2 \%$ dextrose per $1 \mathrm{~L}$ of distilled water, adjusted to $\mathrm{pH} 7.0$ with $6 \mathrm{~N} \mathrm{HCl}$, was autoclaved at $121^{\circ} \mathrm{C}$ for $15 \mathrm{~min}$. Analytical incubations were conducted in $25 \mathrm{~mL}$ of sterile medium held in $125 \mathrm{~mL}$ stainless steel-capped Delong culture flasks that were incubated for $72 \mathrm{~h}$ at $28^{\circ} \mathrm{C}$ on a rotary shaker operating at $250 \mathrm{rpm}$. A $10 \%$ inoculum derived from $72 \mathrm{~h}$ old stage I cultures was used to initiate stage II cultures, which were incubated for $24 \mathrm{~h}$ more before receiving $5 \mathrm{mg}$ of 1 in $0.5 \mathrm{ml} \mathrm{DMF}$ and incubations was continued. Substrate controls consisted of sterile medium and substrate incubated under the same conditions but without microorganism. Samples of $3 \mathrm{~mL}$ were withdrawn for analysis at 24, 48,72 , and $144 \mathrm{~h}$ after substrate addition, extracted with $1 \mathrm{~mL}$ of EtOAc: $n-\mathrm{BuOH}$ (9:1). The organic layer was separated from aqueous medium by centrifugation at $1,200 \mathrm{x} g$ in a desktop centrifuge and $60 \mu \mathrm{L}$ samples were spotted onto TLC plate developed with solvent system using $\mathrm{CH}_{2} \mathrm{Cl}_{2}: \mathrm{MeOH}: \mathrm{CH}_{3} \mathrm{COOH}$ (15: 0.5: $0.3 \mathrm{ml}$ ) as developing solvents. The developed chromatograms were visualized by spraying with vanillin $/ \mathrm{H}_{2} \mathrm{SO}_{4}$, followed by heating with a heating gun until maximum development of the spots color. On the basis of screening experiments, three metabolites were reproducibly formed by Absidia corymbifera (RCMB 051002) after $144 \mathrm{~h}$.

\section{Preparative Biotransformation of caffeic $\operatorname{acid}(1)$ :}

Preparative scale transformation of Caffeic acid by Absidia corymbifera (RCMB 051002) cultures which gave the best results in screening were incubated as before in fifty, $125 \mathrm{~mL}$ stainless steel-capped Delong culture flasks, each containing $25 \mathrm{~mL}$ of medium. Caffeic acid (1), $870 \mathrm{mg}$ was dissolved in $10 \mathrm{mLDMF}$, and evenly distributed among the 24h-old stage-II cultures. After $144 \mathrm{~h}$, the contents of 50 flasks were combined and centrifuged at $10,000 \times \mathrm{g}$ at $4{ }^{\circ} \mathrm{C}$ for $20 \mathrm{~min}$. The supernatant was extracted with three 500 $\mathrm{mL}$ volumes of EtOAc; $\mathrm{n}-\mathrm{BuOH}(9: 1 \mathrm{~V} / \mathrm{V})$. The organic layer was pooled, dried over anhydrous $\mathrm{Na}_{2} \mathrm{SO}_{4}$, filtered through sintered glass, and vacuum-concentrated to yield $820 \mathrm{mg}$ of (1), as viscous brown residue.

\section{Isolation and Purification of the Metabolites:}

The resulting brown residue from fermentation of caffeic acid (1) with Absidia corymbifera $(820 \mathrm{mg})$ was chromatographed over a silica gel column $(1.5 \times 100 \mathrm{~cm}, 100 \mathrm{~g})$ using $n$-hexane gradually enriched with EtOAc (100:0 $\rightarrow 0$ : 100). Fifty millilitre fractions were collected and similar fractions pooled and monitored by TLC, $\left[\mathrm{CH}_{2} \mathrm{Cl}_{2}: \mathrm{MeOH}\right.$ : Acetic acid (15: $0.5: 0.3 \mathrm{ml}$ )], using vanillin $/ \mathrm{H}_{2} \mathrm{SO}_{4}$ as spray reagent to afford three major groups (A-C). Group A (fractions 18-30,105 mg) was further subjected to CC on silica gel $(1.5 \times 50$ $\mathrm{cm}, 50 \mathrm{~g}$ ), isocratically eluted with $5 \%$ EtOAc in hexane. Ten millilitre fractions were collected to afford metabolite (Caff-AM-1) [24 mg, $\mathrm{R}_{f} 0.63, \mathrm{CH}_{2} \mathrm{Cl}_{2}: \mathrm{MeOH}$ : Acetic acid (15: 0.5: $0.3 \mathrm{ml}$ ].Group B (fractions $32-42,80 \mathrm{mg}$ ) was similarly treated as above using $8 \%$ EtOAc in hexane to afford $20 \mathrm{mg}$ of metabolite Caff-AM-2 $\left[\mathrm{R}_{f}, 0.56, \mathrm{CH}_{2} \mathrm{Cl}_{2}: \mathrm{MeOH}\right.$ : 
Acetic acid (15: 0.5: $0.3 \mathrm{ml}$ ].Group C (fractions 44-48, $55 \mathrm{mg}$ ) was purified on a silica gel column and eluted with $n$-hexane gradually enriched with EtOAc $(90: 10 \rightarrow 80: 20)$ to afford a one spot $\left(\mathrm{R}_{f}, 0.50, \mathrm{CH}_{2} \mathrm{Cl}_{2}: \mathrm{MeOH}\right.$ : Acetic acid (15: 0.5: $\left.0.3 \mathrm{ml}, 26 \mathrm{mg}\right)$. It was rechromatographed over Sephadex LH-20 column for final purification eluted with $\mathrm{CH}_{2} \mathrm{Cl}_{2}$ : MeOH: (70:30) to afford caffeic acid metabolite (Caff-AM-3, $12 \mathrm{mg}$ ).

Metabolite [Caff-AM-1]: was obtained as pale yellow amorphous powder. It gave a blue color with vanillin/sulfuric acid. The molecular formula was determined to be $\mathrm{C}_{10} \mathrm{H}_{10} \mathrm{O}_{4}$ by EI-MS m/z (rel. int.): $194(\mathrm{M})^{+}, 167\left(\mathrm{M}-\mathrm{COOH}+\mathrm{H}_{2} \mathrm{O}\right)^{+}, 152\left(\mathrm{M}-\mathrm{COOH}-\mathrm{OH}+\mathrm{H}_{2} \mathrm{O}\right.$ $+\mathrm{H})^{+}, 138\left(\mathrm{M}-\mathrm{COOH}-\mathrm{OH}-\mathrm{CH}_{3}+\mathrm{H}_{2} \mathrm{O}+\mathrm{H}\right)^{+}, 123\left(\mathrm{M}-\right.$ propenoic acid $\left[\mathrm{C}_{3} \mathrm{H}_{4} \mathrm{O}_{2}\right.$, side chain $]+\mathrm{H})^{+}, 110\left(\mathrm{M} \text { - propenoic acid }\left[\mathrm{C}_{3} \mathrm{H}_{4} \mathrm{O}_{2} \text {, side chain }\right]-\mathrm{CH}_{3}+2 \mathrm{H}\right)^{+}$and $91(\mathrm{M}-$ propenoic acid $\left[\mathrm{C}_{3} \mathrm{H}_{4} \mathrm{O}_{2} \text {, side chain] }-\mathrm{OCH}_{3}\right)^{+}$; UV $\lambda_{\max }(\mathrm{MeOH}): 325,290 \mathrm{sh}, 245$ sh, 218 $\mathrm{nm}, \mathrm{IR}(\mathrm{KBr}) \mathrm{cm}^{-1}: 3435(\mathrm{OH}), 1690(\mathrm{C}=\mathrm{O}), 1575$ (aromatic ring), $1620(\mathrm{C}=\mathrm{C}), 1515(-\mathrm{C}-\mathrm{O}$ stretching), 852,802,2875 (CH), 1175-1325 $\left(\mathrm{OCH}_{3}\right) ;{ }^{1} \mathrm{H}-\mathrm{NMR}\left(500 \mathrm{MHz}, \mathrm{CD}_{3} \mathrm{OD}\right): \delta_{\mathrm{H}} 6.43$ $(1 \mathrm{H}, \mathrm{d}, J=2.8 \mathrm{~Hz}, \mathrm{H}-2), 6.75(1 \mathrm{H}, \mathrm{d}, J=8.6 \mathrm{~Hz}, \mathrm{H}-5), 6.17(1 \mathrm{H}, \mathrm{dd}, J=8.6,2.8 \mathrm{~Hz}, \mathrm{H}-6)$, $7.26(1 \mathrm{H}, \mathrm{d}, J=15.6 \mathrm{~Hz}, \mathrm{H}-7), 6.26(1 \mathrm{H}, \mathrm{d}, J=15.6 \mathrm{~Hz}, \mathrm{H}-8), 3.81\left(3 \mathrm{H}, \mathrm{s}, \mathrm{OCH}_{3}-3\right)$

Metabolite [Caff-AM-2]: was obtained as pale yellow amorphous powder. It gave a dark blue color with vanillin/sulfuric acid. The molecular formula was determined to be $\mathrm{C}_{11} \mathrm{H}_{14} \mathrm{O}_{4}$ by EI-MS m/z (rel. int.): $209(\mathrm{M}-\mathrm{H})^{+}, 192\left(\mathrm{M}+\mathrm{H}-\mathrm{H}_{2} \mathrm{O}\right)^{+}, 165(\mathrm{M}+\mathrm{H}-$ $\mathrm{COOH})^{+}, 152\left(\mathrm{M}+\mathrm{H}-\mathrm{COOH}-\mathrm{CH}_{3}\right)^{+}, 137$ (M- propenoic acid $\left(\mathrm{C}_{3} \mathrm{H}_{4} \mathrm{O}_{2} \text {, side chain }\right)^{+}, 124$ $\left(\mathrm{M}+\mathrm{H} \text { - propenoic acid }\left[\mathrm{C}_{3} \mathrm{H}_{4} \mathrm{O}_{2} \text {, side chain }\right]-\mathrm{CH}_{3}\right)^{+}$, and $109(\mathrm{M}+\mathrm{H}$ - propenoic acid $\left[\mathrm{C}_{3} \mathrm{H}_{4} \mathrm{O}_{2}\right.$, side chain $\left.]-2 \mathrm{CH}_{3}\right)^{+}$; UV $\lambda_{\max }(\mathrm{MeOH}): 285,250,325, \mathrm{IR}(\mathrm{KBr}) \mathrm{cm}^{-1}: 3425(\mathrm{OH})$, $1680(\mathrm{C}=\mathrm{O}), 1570$ (aromatic ring),1630 $(\mathrm{C}=\mathrm{C}), 1510$ (-C-O stretching),1180 (OH), $850,810,2850(\mathrm{CH}), 1170-1345\left(\mathrm{OCH}_{3}\right) ;{ }^{1} \mathrm{H}$ NMR $\left(500 \mathrm{MHz}, \mathrm{CD}_{3} \mathrm{OD}\right): \delta_{\mathrm{H}} 6.52(1 \mathrm{H}, \mathrm{d}, J=2.5$ $\mathrm{Hz}, \mathrm{H}-2), 6.94(1 \mathrm{H}, \mathrm{d}, J=8.6 \mathrm{~Hz}, \mathrm{H}-5), 7.12(1 \mathrm{H}, \mathrm{dd}, J=8.6,2.5 \mathrm{~Hz}, \mathrm{H}-6), 7.54(1 \mathrm{H}, \mathrm{d}, J=$ $16.2 \mathrm{~Hz}, \mathrm{H}-7), 6.39(1 \mathrm{H}, \mathrm{d}, J=16.2 \mathrm{~Hz}, \mathrm{H}-8), 3.86\left(3 \mathrm{H}, \mathrm{s}, \mathrm{OCH}_{3}-3\right), 3.83\left(3 \mathrm{H}, \mathrm{s}, \mathrm{OCH}_{3}-4\right)$

Metabolite [Caff-AM-2]: was obtained as a colorless powder. It gave a dark blue color with vanillin/sulfuric acid. The molecular formula was determined to be $\mathrm{C}_{9} \mathrm{H}_{10} \mathrm{O}_{2}$ by EIMS $m / z$ (rel. int.): $150(\mathrm{M})^{+}, 112\left(\mathrm{M}-2 \mathrm{H}-2 \mathrm{H}_{2} \mathrm{O}\right)^{+}, 90\left(\mathrm{M}-\right.$ prop-2-en-1-ol $\left[\mathrm{C}_{3} \mathrm{H}_{6} \mathrm{O}\right.$, side chain] $-2 \mathrm{H})^{+}, 90\left(\mathrm{M}-\mathrm{CH}_{2} \mathrm{OH}-\mathrm{OH}\right)^{+}$.; UV $\lambda_{\max }(\mathrm{MeOH}): 265,315 \mathrm{~nm}, \mathrm{IR}(\mathrm{KBr}) \mathrm{cm}_{-1}: 3510(\mathrm{OH})$, $1680(\mathrm{C}=\mathrm{O}), 1545$ (aromatic ring), 1640 $(\mathrm{C}=\mathrm{C}), 1520$ (-C-O stretching), $1180(\mathrm{OH})$, $855,815,2875(\mathrm{CH}) ;{ }^{1} \mathrm{H}-\mathrm{NMR}\left(500 \mathrm{MHz}, \mathrm{CD}_{3} \mathrm{OD}\right): \delta_{\mathrm{H}} 7.18(2 \mathrm{H}, \mathrm{d}, J=8.6 \mathrm{~Hz}, \mathrm{H}-2,6), 6.94$ $(2 \mathrm{H}, \mathrm{d}, J=8.6 \mathrm{~Hz}, \mathrm{H}-3,5), 6.58(1 \mathrm{H}, \mathrm{d}, J=16.5 \mathrm{~Hz}, \mathrm{H}-7), 7.57(1 \mathrm{H}, \mathrm{dt}, J=16.5,6.5 \mathrm{~Hz}, \mathrm{H}-$ 8), $4.73(1 \mathrm{H}, \mathrm{dd}, J=13.5,6.5 \mathrm{~Hz}, \mathrm{H}-9 \mathrm{a}), 4.81(1 \mathrm{H}, \mathrm{dd}, J=13.5,6.5 \mathrm{~Hz}, \mathrm{H}-9 \mathrm{~b})$

\section{In-Vitro Biological Evaluation:}

Antioxidant activity: The antioxidant activity of 2,5dihydroxycinnamic acid(1) and its metabolites[Caff-AM-1-AM-3], were analyzed using two different techniques; DPPH radical scavenging activity and $\mathrm{FeSO}_{4} / \mathrm{H}_{2} \mathrm{O}_{2}$-stimulated lipid peroxidation in rat tissue homogenate.

Chemicals: 1,1-Diphenyl-2-picrylhydrazyl (DPPH), butylatedhydroxytoluene (BHT), 2thiobarbituric acid, ferrous sulphate, hydrogen peroxide, were purchased from Sigma Chemical Company (St. louis, Mo, USA).

Animals: Male Westar rats (250-300 g) were handled according to international regulations. They were allowed to take standard laboratory diet and water ad libitum, and the animals were maintained at $24{ }^{\circ} \mathrm{C}$ with $12 \mathrm{~h}$ light period.

\section{A. DPPH radical scavenging activity}

The ability of the extracts to scavenge free radicals was determined according to the method of De La Torre Boronat and LopezTamames (1997). In a 96-well plate, $10 \mu \mathrm{L}$ of 
each sample or standard dissolved in ethanol $(100 \mu \mathrm{g} / \mathrm{mL})$ was added to $190 \mu \mathrm{L}$ of 316 $\mu \mathrm{M} / \mathrm{mL}$ DPPH solution. A blank was prepared using ethanol. After incubation at $30^{\circ} \mathrm{C}$ for 30 min, the absorbance of each solution was measured at $517 \mathrm{~nm}$. DL- $\alpha$-tocopherol and BHT were used as positive controls. The scavenging activity of the samples was calculated as a percentage of free radical inhibition according to the formula:

$$
\% \text { inhibition }=\frac{\mathbf{A}_{\text {blank }}-\mathbf{A}_{\text {sample }}}{\mathbf{A}_{\text {blank }}} \times 100
$$

Where ${ }^{A}$ blank is the absorbance of the blank at zero time and ${ }^{A}$ sample is the absorbance of the sample after $30 \mathrm{~min}$. All experiments were carried out in triplicate.

\section{B. $\mathrm{FeSO}_{4} / \mathrm{H}_{2} \mathrm{O}_{2}$-stimulated lipid peroxidation in rat tissue homogenate (Taha et al.,} 2011).

Male Westar rats (250-300 g) were sacrificed, and the rat tissues (brain, heart and liver: $0.3-0.5 \mathrm{~g}$ ) were rapidly removed and homogenized in 10 volumes of $15 \mathrm{mM}$ Krebs buffer. Homogenates were centrifuged at $3000 \mathrm{x}$ for 10 minutes at $4{ }^{\circ} \mathrm{C}$ to give supernatants containing (1.2 mg of protein/ ml; brain), (1.7 mg of protein/ ml; heart) and $(2.5 \mathrm{mg}$ of protein/ ml; liver) using Coomassie plus protein assay reagent and albumin standard as determined by the Bradford method (Bradford, 1976). During aerobic incubation of the tissue homogenates, MDA released reacts with thiobarbituric acid (TBA) to give a pink color. The capability of the samples to inhibit MDA formation is used as a measure of their antioxidant activity. The pink color complex of thiobarbituric acid reacting substance (TBARS) is measured at $532 \mathrm{~nm}$ for the test samples and positive standards (DL- $\alpha-$ tocopherol and BHT) $(200 \mu \mathrm{g} / \mathrm{mL})$, as well as, caffeic acid (1) and their metabolites (CaffAM-1-AM-3, $100 \mu \mathrm{g} / \mathrm{mL}$ ). The results were expressed as nano-moles of MDA equivalents per milligram of protein of rat (brain, heart and liver) homogenates. All measurements were done in triplicate. The capability to inhibit MDA formation was calculated using the following equation:

Inhibition effects $(\%)=1-\frac{\text { MDA in tissue homogenate with test extracts }}{\text { MDA in tissue homogenate without test extracts }} \times 100$

\section{Statistical Analysis}

All data were expressed as mean \pm SE. Student's t-test [33] was applied for detecting the significance of difference between each sample; $\mathrm{P}<0.05$ was taken as the level of significance.

\section{RESULTS AND DISCUSSION}

\section{A- Structure Elucidation of isolated metabolites:}

Of 11 microorganisms screened for their abilities to catalyze the bioconversion of caffeic acid (1), Absidia corymbifera (RCMB 051002) reproducibly formed after $144 \mathrm{~h}$ of incubation three major metabolites [Caff-AM-1-AM-3]. None of the observed metabolites were formed in control cultures or in media containing no microorganisms but incubated under the same conditions. Following solvent extraction and column chromatographic 
purification, samples of metabolites were subjected to spectral analysis. Spectra (UV, IR, NMR, and mass spectrometry) for isolated metabolites were established by comparing their spectral data to those given in the literature.

\section{Metabolite [Caff-AM-1]}

Was obtained as pale yellow amorphous powder. It gave a blue color with vanillin/sulfuric acid. [Caff-AM-1] exhibited UV absorptions confirming its phenolic nature at $(325,290 \mathrm{sh}, 245 \mathrm{sh}, 218 \mathrm{~nm})$. The IRspectrum exhibited sharp absorption band at 3450 $\mathrm{cm}^{-1}$ for OH group of carboxylic acid, an absorption band at $1690 \mathrm{~cm}^{-1}$ for $-\mathrm{C}=\mathrm{O}$ of carboxylic acid and an absorption band near $1620 \mathrm{~cm}^{-1}$ for $-\mathrm{C}=\mathrm{C}$ - stretching. The band at $1175-1325 \mathrm{~cm}^{-1}$ showed presence of methoxy group ( $-\mathrm{C}-\mathrm{O}$ stretching frequency).The molecular formula was determined as $\mathrm{C}_{10} \mathrm{H}_{10} \mathrm{O}_{4}$ on the basis of the molecular ion peaks observed at $\mathrm{m} / \mathrm{z} 194(\mathrm{M})^{+}$, $167\left(\mathrm{M}-\mathrm{COOH}+\mathrm{H}_{2} \mathrm{O}\right)^{+}, 152\left(\mathrm{M}-\mathrm{COOH}-\mathrm{OH}+\mathrm{H}_{2} \mathrm{O}+\mathrm{H}\right)^{+}, 138\left(\mathrm{M}-\mathrm{COOH}-\mathrm{OH}-\mathrm{CH}_{3}+\right.$ $\left.\mathrm{H}_{2} \mathrm{O}+\mathrm{H}\right)^{+}, 123$ (M- propenoic acid $\left[\mathrm{C}_{3} \mathrm{H}_{4} \mathrm{O}_{2}\right.$, side chain $\left.]+\mathrm{H}\right)^{+}, 110$ (M- propenoic acid $\left[\mathrm{C}_{3} \mathrm{H}_{4} \mathrm{O}_{2} \text {, side chain] }-\mathrm{CH}_{3}+2 \mathrm{H}\right)^{+}$and 91 (M- propenoic acid $\left[\mathrm{C}_{3} \mathrm{H}_{4} \mathrm{O}_{2}\right.$, side chain] $\left.\mathrm{OCH}_{3}\right)^{+}$by EI-MS.

The ${ }^{1} \mathrm{H}-\mathrm{NMR}$ spectrum of [Caff-AM-1], exhibited three aromatic proton signals as an ABX Spin-system at $\delta_{\mathrm{H}} 6.43(1 \mathrm{H}, \mathrm{d}, J=2.8 \mathrm{~Hz}, \mathrm{H}-2), 6.75(1 \mathrm{H}, \mathrm{d}, J=8.6 \mathrm{~Hz}, \mathrm{H}-5)$ and6.17 $(1 \mathrm{H}, \mathrm{dd}, J=8.6,2.8 \mathrm{~Hz}, \mathrm{H}-6)$, indicating the presence of a tri-substituted aromatic ring in the molecule. The ${ }^{1} \mathrm{H}-\mathrm{NMR}$ spectrum also displayed two doublet protons as an $\mathrm{AB}$ spin-system $(J$ $=15.6 \mathrm{~Hz})$, each for $1 \mathrm{H}$, at $\delta_{\mathrm{H}} 7.26(\mathrm{H}-7)$ and $6.26(\mathrm{H}-8)$. The large value of coupling constant indicated the presence of trans-disubstituted ethylene moiety in the molecule. The downfield signal for three hydrogens at $\delta_{\mathrm{H}} 3.81$ indicates that methyl group is attached to electron withdrawing oxygen atom of $\mathrm{OCH}_{3}$ group. The molecular ion peak atm/z $194(\mathrm{M})^{+}$with 14 mass unit over that of substrate and the ${ }^{1} \mathrm{H}-\mathrm{NMR}$ spectrum of [Caff-AM-1] revealed that this metabolite had the same carbon skeleton as [substrate] with one methoxyl group versus a hydroxyl group in [substrate].

On the basis of these spectral data [Caff-AM-1] was characterized as Ferulic acid; (3methoxy-4-hydroxy cinnamic acid) (Rosazza et al., 1995).

\section{Metabolite [Caff-AM-2]}

Was obtained as pale yellow amorphous powder. It gave a dark blue color with vanillin/sulfuric acid. [Caff-AM-2] exhibited UV absorptions confirming its phenolic nature at $\lambda_{\max } 285,250,325 \mathrm{~nm}$. The IRspectrum exhibited sharp absorption band at $3425 \mathrm{~cm}^{-1}$ for OH group of carboxylic acid, an absorption band at $1680 \mathrm{~cm}^{-1}$ for $-\mathrm{C}=\mathrm{O}$ of carboxylic acid, an absorption band at $1570 \mathrm{~cm}^{-1}$ for aromatic ring and an absorption band near $1630 \mathrm{~cm}^{-1}$ for $\mathrm{C}=\mathrm{C}-$ stretching. The band at $1170-1345 \mathrm{~cm}^{-1}$ showed presence of methoxy group ( $-\mathrm{C}-\mathrm{O}$ stretching frequency). The molecular formula was determined as $\mathrm{C}_{11} \mathrm{H}_{12} \mathrm{O}_{4}$ on the basis of the molecular ion peaks observed at m/z $209(\mathrm{M}-\mathrm{H})^{+}, 192\left(\mathrm{M}+\mathrm{H}-\mathrm{H}_{2} \mathrm{O}\right)^{+}, 165(\mathrm{M}+\mathrm{H}-$ $\mathrm{COOH})^{+}, 152\left(\mathrm{M}+\mathrm{H}-\mathrm{COOH}-\mathrm{CH}_{3}\right)^{+}, 137\left(\mathrm{M}\right.$ - propenoic acid $\left(\mathrm{C}_{3} \mathrm{H}_{4} \mathrm{O}_{2} \text {, side chain }\right)^{+}, 124(\mathrm{M}$ $+\mathrm{H}$ - propenoic acid $\left[\mathrm{C}_{3} \mathrm{H}_{4} \mathrm{O}_{2}\right.$, side chain $\left.]-\mathrm{CH}_{3}\right)^{+}$and $109\left(\mathrm{M}+\mathrm{H}\right.$ - propenoic acid $\left[\mathrm{C}_{3} \mathrm{H}_{4} \mathrm{O}_{2}\right.$, side chain $\left.]-2 \mathrm{CH}_{3}\right)^{+}$by EI-MS.

The ${ }^{1} \mathrm{H}-\mathrm{NMR}$ spectrum of [Caff-AM-2], exhibited three aromatic proton signals as an ABX Spin-system at $\delta_{\mathrm{H}} 6.52(1 \mathrm{H}, \mathrm{d}, J=2.5 \mathrm{~Hz}, \mathrm{H}-2), 6.94(1 \mathrm{H}, \mathrm{d}, J=8.6 \mathrm{~Hz}, \mathrm{H}-5)$ and7.12 $(1 \mathrm{H}, \mathrm{dd}, J=8.6,2.5 \mathrm{~Hz}, \mathrm{H}-6)$,indicating the presence of a tri-substituted aromatic ring in the molecule. The ${ }^{1} \mathrm{H}-\mathrm{NMR}$ spectrum also displayed two doublet protons as an AB spin-system $(J$ $=16.2 \mathrm{~Hz})$, each for $1 \mathrm{H}$, at $\delta_{\mathrm{H}} 7.54(\mathrm{H}-7)$ and $6.39(\mathrm{H}-8)$. The large value of coupling constant indicated the presence of trans-disubstituted ethylene moiety in the molecule. On the other hand the presence of signals for two singlet methoxyl groups at $\delta_{\mathrm{H}} 3.86\left(3 \mathrm{H}, \mathrm{s}, \mathrm{OCH}_{3}-3\right)$ and $3.83\left(3 \mathrm{H}, \mathrm{s}, \mathrm{OCH}_{3}-4\right)$ indicates that two methyl groups were attached to electron withdrawing oxygen atom of $\mathrm{OCH}_{3}$ groups. These NMR data revealed that metabolite[Caff-AM-2] had the 
same proton skeleton as in metabolite [Caff-AM-1]with additional signals arising from one more methoxyl group that was also confirmed from ion peak at $\mathrm{m} / \mathrm{z}$ its $209(\mathrm{M}-\mathrm{H})^{+}$versus ion peak at $\mathrm{m} / \mathrm{z}$ 194(M) ${ }^{+}$in metabolite [Caff-AM-1].

From these results, the structure of metabolite [Caff-AM-2] was concluded to be 3,4dimethoxy-cinnamic acid[(E)-3-(3,4-dimethoxy-phenyl)-propenoic acid].

\section{Metabolite [Caff-AM-3]}

Was obtained as white powder. It gave a dark blue color with vanillin/sulfuric acid and exhibited UV absorptions confirming its phenolic nature at $\left(\lambda_{\max } 265\right.$ and $\left.315 \mathrm{~nm}\right)$. The IR spectrum of [Caff-AM-3] showed absorption bands at 3510, 1680, 1640 and $1545 \mathrm{~cm}^{-1}$ ascribable to hydroxyl, carbonyl, olefin and aromatic ring functionalities, respectively. The molecular formula $\mathrm{C}_{9} \mathrm{H}_{10} \mathrm{O}_{2}$ of [Caff-AM-3]was determined from the molecular ion base peak at $m / z 150(\mathrm{M})^{+}$together with fragment ion peaks at $m / z 112\left(\mathrm{M}-2 \mathrm{H}-2 \mathrm{H}_{2} \mathrm{O}\right)^{+}, \mathrm{m} / z 90$ for $(\mathrm{M}$ - prop-2-en-1-ol $\left[\mathrm{C}_{3} \mathrm{H}_{6} \mathrm{O} \text {, side chain] }-2 \mathrm{H}\right)^{+}$or $\left(\mathrm{M}-\mathrm{CH}_{2} \mathrm{OH}-\mathrm{OH}\right)^{+}$observed in the electron impact (EI)-MS.

The ${ }^{1} \mathrm{H}-\mathrm{NMR}$ resonances of [Caff-AM-3], clearly showed signals typically found in a $p$-coumaryl alcohol ${ }^{(204)}$. It showed, four aromatic protons at $\delta_{\mathrm{H}} 7.18(2 \mathrm{H}, \mathrm{d}, J=8.6 \mathrm{~Hz}, \mathrm{H}-2$, H-6) and $\delta_{\mathrm{H}} 6.94(2 \mathrm{H}, \mathrm{d}, J=8.6 \mathrm{~Hz}, \mathrm{H}-3, \mathrm{H}-5)$ represented AA' BB' spin-pattern of 4'oxygenated B-ring. In the ${ }^{1} \mathrm{H}-\mathrm{NMR}$ spectrum of [Caff-M-3], also showed signals due to a hydroxy-methylene at $\delta_{\mathrm{H}} 4.73(1 \mathrm{H}, \mathrm{dd}, J=13.5,6.5 \mathrm{~Hz}, \mathrm{H}-9 \mathrm{a})$, and $\delta_{\mathrm{H}} 4.81(1 \mathrm{H}, \mathrm{dd}, J=$ $13.5,6.5 \mathrm{~Hz}, \mathrm{H}-9 \mathrm{~b})$ and two olefinic protons as an $\mathrm{AB}$ spin-system at $\delta_{\mathrm{H}} 6.58(1 \mathrm{H}, \mathrm{d}, J=16.5$ $\mathrm{Hz}, \mathrm{H}-7)$ and $7.57(1 \mathrm{H}, \mathrm{dt}, J=16.5,6.5 \mathrm{~Hz}, \mathrm{H}-8)$, which could be assigned to an transcinnamoyl moiety.

Onthe basis of these findings, the structure of metabolite [Caff-AM-3],was determined to bep-coumaryl alcohol[4-hydroxycinnamyl alcohol] (Hosoya et al., 2008).

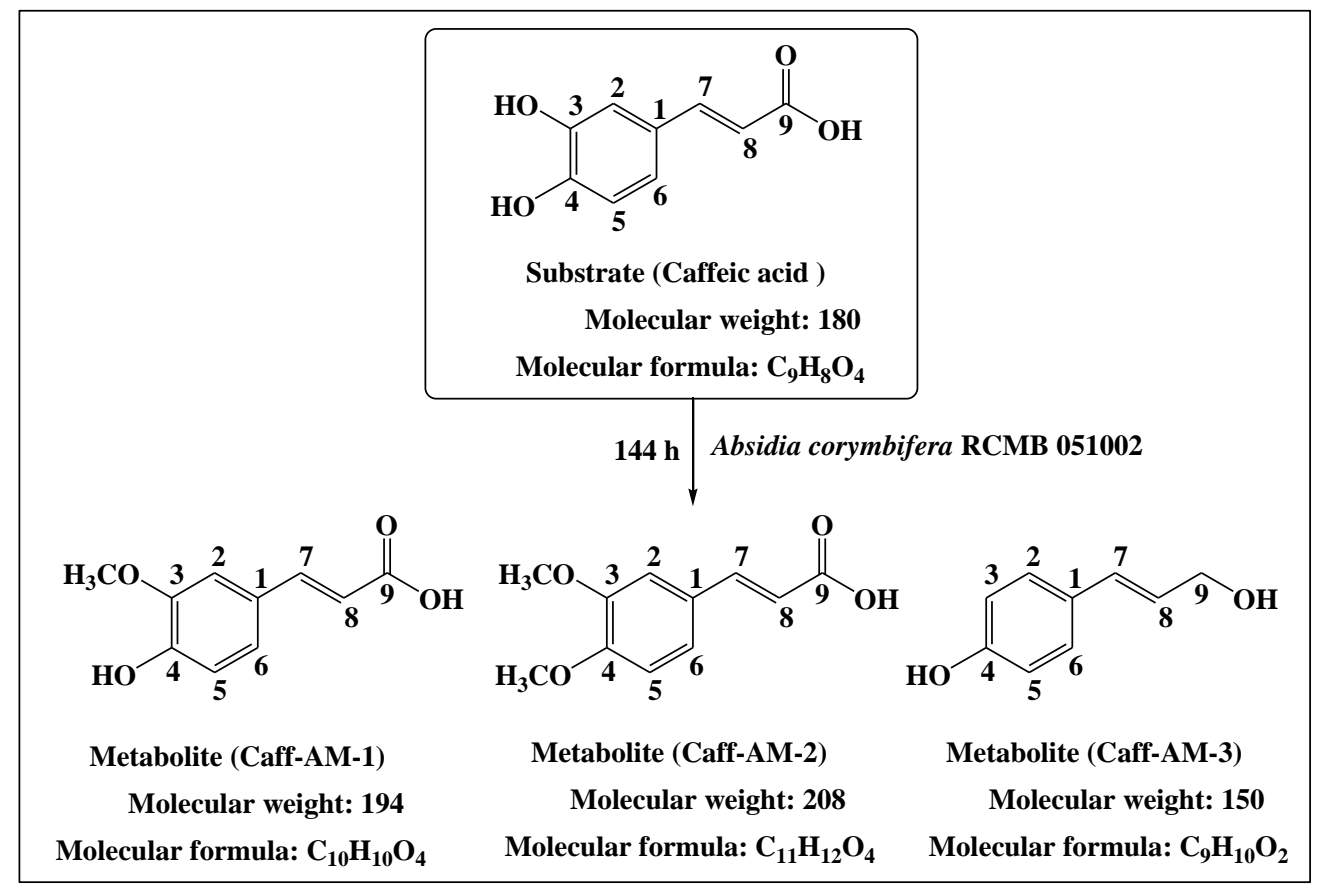

(Figure 1) Structure of Caffeic acid(1) and its metabolites. 


\section{CONCLUSION}

Caffeic acid is structurally a relatively simple compound however it contains several metabolically active sites, a property that leads to the formation of a large number of metabolites. The $O$-methylation of caffeic acid through the catalytic activity of Catechol- $O$ methylt-ransferase (COMT) has ken surmised to be a major route of metabolism of caffeic acid though significant amounts of ferulic acid were found in the urine following the oral administration of caffeic acid to human and rats (Nardini et al., 1997). Catechol-Omethyltransferase is an $S$-adenosyl-L-methionine-dependent methyl-transferase enzyme that catalyzes the methylation of catechol substrates. Physiologically, it is responsible for the elimination of biologically active or toxic catechols, making it a protein with great clinical relevance as therapeutic target in serious disorders, like schizophrenia and Parkinson's disease (Maria-Joao et al., 2007).The active site of COMT suggested that the methyl building unit is supplied from L-methionine which activates one of the substrate catecholic hydroxylic groups and is introduced by a nucleophilic substitution reaction. In nature, the leaving group is enhanced by converting L-methionine into $S$-adenosylmethionine (SAM) (Figure 2a). This gave positively charged sulfur and facilitates the $S N^{2}$-type nucleophilic substitution mechanism (Figure $2 \mathrm{~b}$ ). Thus, $O$-methyl linkage may be obtained using hydroxyl and amino functions as nucleophiles. Methionine is subsequently regenerated by the methylation of homocysteine, using $N^{5}$-methyl-tetrahydrofolate as methyl donor. The active site of COMT suggested that the methylation of catechols involved a lysine as a general base, which activates one of the substrate catecholic hydroxylic groups for a nucleophilic attack on the active methyl group of the coenzyme SAM (Maria-Joao et al., 2007).

Our results suggest that the preferred route of caffeic acid metabolism by Absidia corymbifera may involve many enzymes (Figure 3). Caffeic acid can be metabolized sequentially by COMT to form their $O$-methylated products, ferulic acid (Caff-AM-1) and (E)-3-(3,4-dimethoxy-phenyl) propenoic acid(Caff-AM-2). We have speculated that $p$ coumarylalcohol(Caff-AM-3), was formed from caffeic acid (substrate) first by dehydroxylation yielding the intermediate 4-coumaric acid ( $p$-coumaric acid) following by reduction of $p$-coumaric acid via coenzyme $\mathrm{A}$ ester and aldehyde leads to the corresponding alcohol through oxidation reaction with the $\beta$-oxidation enzyme acyl CoA dehydrogenase to form their unsanirated product $p$-coumaric acid. Formation of the coenzyme A ester facilitates the first reduction step by introducing a better leaving group $\left(\mathrm{CoAS}^{-}\right)$for the NADPH-dependent reaction. The second reduction step, aldehyde to alcohol, utilizes a further molecule of NADPH (Figure 3). Therefore, it has been well established that enzyme systems capable of performing metabolic processes of caffeic acid involves methylation, dehydroxylation and hydrogenation are functioning continuously.

\section{B- Results of Biological evaluation (Antioxidant Activities)}

Free radicals are a major cause of oxidative stress that may lead to DNA strand breakage, gene mutation and DNA-DNA and DNA-protein cross links. Free radicals are known to be a product of normal metabolism. When oxygen is supplied in excess or its reduction is insufficient, reactive oxygen species (ROS) such as hydroxyle $\left(\mathrm{OH}^{-}\right)$, superoxide $\left(\mathrm{O} 2^{-}\right)$, nitric oxide (NO), lipid peroxyle ( $\left.\mathrm{Loo}^{-}\right)$, radical and non-free radical species such as lipid peroxide (LOOH-) and different forms of activated oxygen (Ibrahim et al., 2011). ROS are involved in an organism's vital activities including phagocytosis, regulation of cell proliferation, intracellular signaling and synthesis of biologically active compounds (Ibrahim et al., 2011). ROS have been implicated in several diseases including carcinogenesis, malaria, heart diseases, arteriosclerosis, diabetes and many other health problems, (Ibrahim et al.,2011). The role of ROS in the a etiology and progression of several clinical manifestations 
has led to the suggestion that the antioxidants can be beneficial as prophylactic agents. Nevertheless, all aerobic organisms, including humans, have antioxidant defenses that protect against oxidative harm and repair damaged molecules. However, the natural antioxidant mechanisms can be insufficient, the supply of antioxidants through dietary ingredients, is of great interest for a healthy life (Ibrahim et al., 2011). In this study caffeic acid (1) and its metabolites were investigated for their antioxidant properties using1,1-diphenyl-2picrylhydrazyl (DPPH) radical scavenging assay and measurement of $\mathrm{FeSO}_{4} / \mathrm{H}_{2} \mathrm{O}_{2}$-stimulated lipid peroxidation in rat tissue homogenates.

\section{B.1- Assay for DPPH free radical scavenging activity}

2,2-Diphenyl-1-picryl hydrazyl (DPPH) is a stable free radical and accepts an electron or hydrogen radical to become a stable diamagnetic molecule (Kuo et al., 1999). The DPPH radical is considered to be a model of a lipophilic radical. A chain reaction in lipophilic radicals was initiated by the lipid autoxidation. The purpose of this study was to evaluate the antioxidant activites of the substrate; caffeic acid and its isolated metabolites obtained by Absidia corymbifera cultures as new potential sources of natural antioxidants. Well known antioxidant D, L- $\alpha$-tocopherol and butylated-hydroxyl toluene(BHT) were used for comparison. The scavenging effects of substrate, metabolites and positive controls D, L, $\alpha-$ tocopherol and BHT on DPPH radical are compared and shown in (Table 1). It was observed that Caffeic acid (1) showed DPPH quenching with $\mathrm{IC}_{50}$ values at $(62.2 \%)$ ). Metabolites; Caff-AM-1 (ferulic acid) highest activity among all the tested samples $(69.3 \%)$, followed by

Caff-AM-2 (3,4-dimethoxy-cinnamic acid) (66.5\%), in DPPHradical quenching, than those of such typical antioxidants D, L, $\alpha$-tocopherol (62.8\%) and BHT (50.2\%) respectively.

Caff-AM-3 (p-coumaryl alcohol) [51.6\%], showed slightly less DPPH radical quenching than D,L, $\alpha$-tocopherol but its more than BHT.

In conclusion, the results obtained with isolated metabolites have indicated that scavenging effects is dependent on their chemical structure and thought to be due to their hydrogen donating activity. In general phenolic $\mathrm{OH}$ is known as scavenger of free radicals and it consequently exhibits anti-oxidative activity (Hosny et al., 2002). Especially, in regards to substitution on the phenyl ring. Several studies have reported that the existence of an electron donating group such as methoxyl substitution as with several metabolites obtained in this study enhances antioxidant effectiveness (Hosny et al., 2002), claimed that the phenolic group is essential for the free-radical-scavenging activity and that the presence of the methoxy group further increased the activity.

Table (1) Effects of caffeic acid, its metabolites and positive controls on the in vitro Free Radical Generation.

\begin{tabular}{|c|c|}
\hline Bioassay & DPPH \% decoloration \\
\hline \multicolumn{2}{|c|}{ Substrate } \\
\hline Caffeic acid & $62.2 \pm 1.50$ \\
\hline \multicolumn{2}{|c|}{ Metabolite } \\
\hline Caff-AM-1 & $\mathbf{6 9 . 3} \pm \mathbf{1 . 6 0}$ \\
\hline Caff-AM-2 & $\mathbf{6 6 . 5} \pm \mathbf{1 . 5 5}$ \\
\hline Caff-AM-3 & $51.6 \pm 1.30$ \\
\hline \multicolumn{2}{|c|}{ Positive control } \\
\hline D,L, $\alpha$-tocopherol & $\mathbf{6 2 . 8 \pm 1 . 5 0}$ \\
\hline BHT & $\mathbf{5 0 . 2 \pm 1 . 3 0}$ \\
\hline
\end{tabular}

Values are presented as mean \pm SE of 3-test sample observation. $P<0.05$ for all values. 


\section{B.2- Ferrous sulphate- $\mathrm{H}_{2} \mathrm{O} 2$-stimulated lipid peroxidation in rat tissue homogenate.}

Lipid peroxidation is a free radical mediated process which has been implicated in a variety of disease states. It involves the formation and propagation of lipid radicals, uptake of oxygen, a re-arrangement of the double and unsaturated lipids that results in a variety of degraded products (e.g., alkenes, malon-dialdehyde (MDA), lipid hydro-peroxides and conjugated dienes that eventually causes destruction of membrane lipids. Thus lipid peroxidation and conjugated diene measurement plays important role along with MDA assay (Halliwell and Chirico, 1993). The increased peroxidation can result in changes in cellular metabolism of the hepatic and extra-hepatic tissues. Increase in accumulation of MDA, conjugated diene and hydro-peroxides in cells can result in cellular dehydration and whole cell deformity and death (Halliwell and Chirico, 1993). It is well known that defense mechanism in liver, kidney, heart, brain and lungs are prone to oxidative damage. Alteration of fatty acid composition by increased lipid levels may contribute for lowering the resistance of tissues and higher rate of oxidative stress. 
Alkylation reactions: nucleophilic substitution (a) formation of SAM
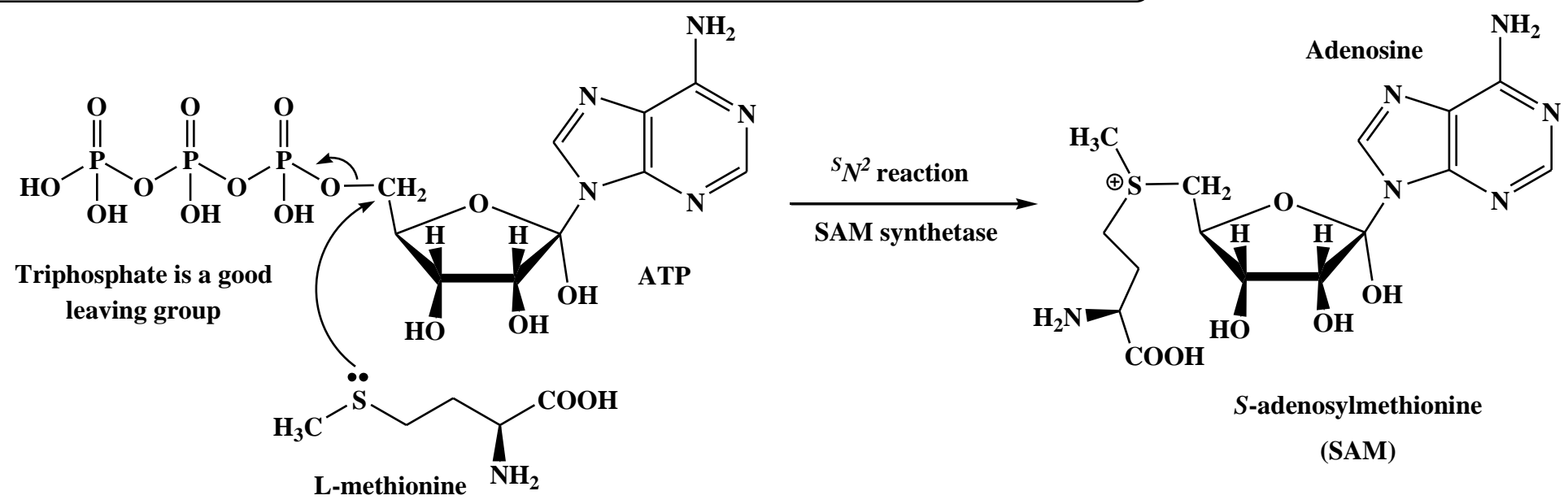

(b) Q-alkylation using SAM; regeneration of methionine

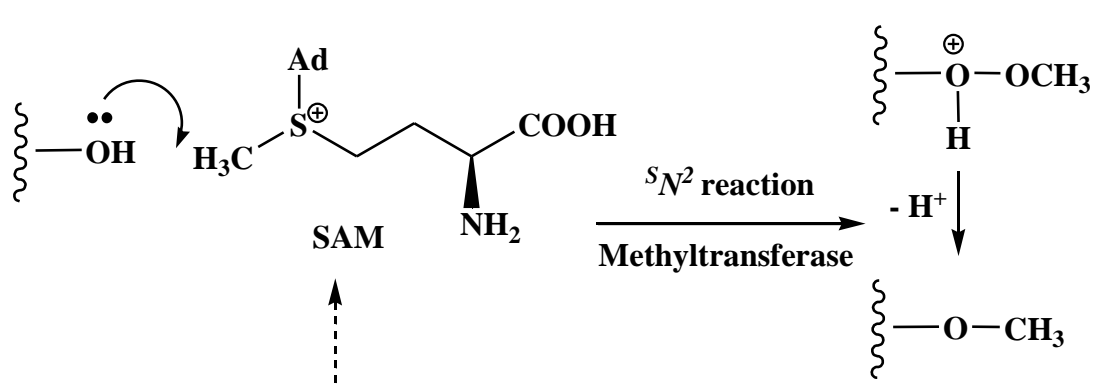

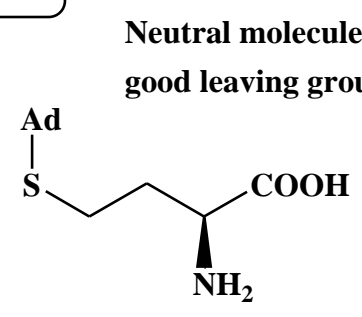

S-adenosylhomocysteine

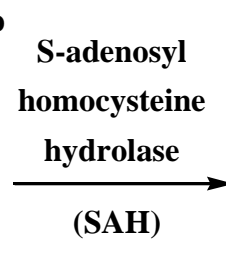

(SAH)

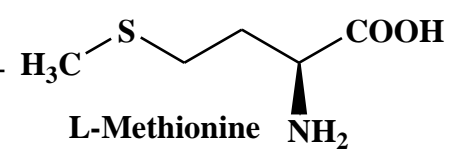

(Figure 2)Formation of SAM and Alkylation reactions. 


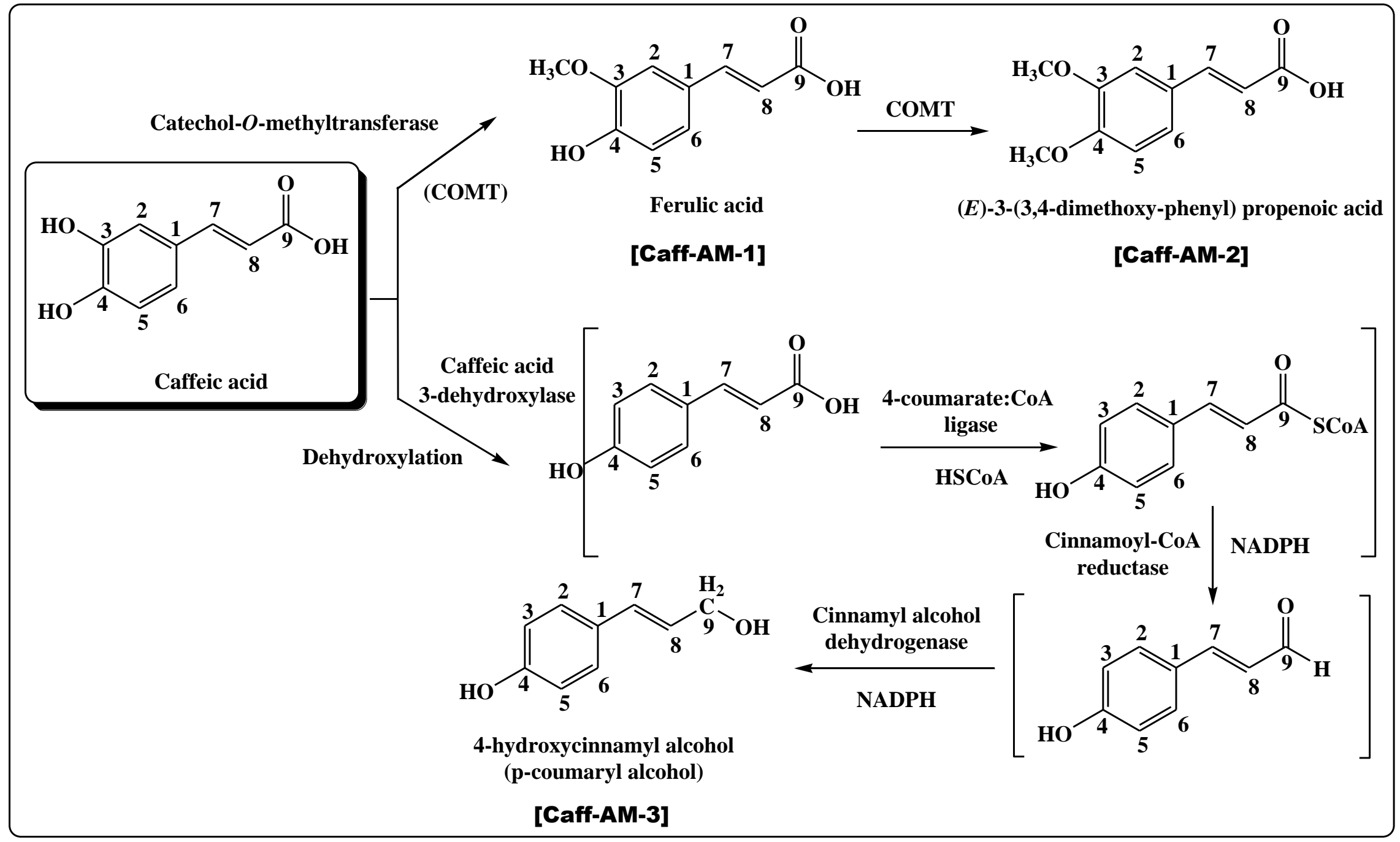

(Figure 3)Possible metabolic pathways of caffeic acid by Absidia corymbifera RCMB 051002. 
There is good evidence that superoxidedismutase (SOD) and catalase are enzymes that scavenge free radicals during lipid peroxidation. The free radical chain reaction is widely accepted as a common mechanism of lipid peroxidation. Radical scavengers may directly react with and quench peroxide radicals to terminate the peroxidation chain reaction and improve the quality and stability of food products (Halliwell and Chirico, 1993).

For rat tissue homogenate (brain, heart and liver), the unstimulated control experiments the amount of thiobarbituric reactive substance (TBARS) [MDA levels without $\left.\mathrm{FeSO}_{4}-\mathrm{H}_{2} \mathrm{O}_{2}\right]$ formed in rat tissue homogenate (brain, heart and liver) were $(0.36 \pm 0.15$ $\mathrm{nmol}, \mathrm{MDA} / \mathrm{mg}$ protein $),(0.22 \pm 0.10 \mathrm{nmol}, \mathrm{MDA} / \mathrm{mg}$ protein $)$ and $(0.16 \pm 0.05 \mathrm{nmol}$, MDA/mg protein), respectively. After induction with $200 \mu \mathrm{m} \mathrm{Fe} e^{2+}-\mathrm{H}_{2} \mathrm{O}_{2}$, The amount of TBARS increased to $(0.72 \pm 1.30 \mathrm{nmol}, \mathrm{MDA} / \mathrm{mg}$ protein $), 0.65 \pm 1.25 \mathrm{nmol}, \mathrm{MDA} / \mathrm{mg}$ protein) and $(0.44 \pm 1.15 \mathrm{nmol}, \mathrm{MDA} / \mathrm{mg}$ protein) of brain, heart and liver, respectively (Table 2).A control experiment indicated that substrates and isolated fungal metabolites did not affect the measurement of TBARS because the absorbance at $532 \mathrm{~nm}$ was not affected by adding different substrates and isolated fungal metabolites to the rat tissue homogenate that already have been oxidatively modified because omission of rat homogenate from the reaction mixture abolished chromogen formation. D, L- $\alpha$-tochopherol and BHT also inhibited this $\mathrm{Fe}^{2+}$-induced lipid peroxidation with $\mathrm{IC}_{50}$ values in the range of (28.23$35.10 \%),(22.05-38.70 \%)$ and $(33.15-46.18 \%)$ in heart, brain and liver rat tissue homogenates, respectively. However, as shown in (Table 2), adding 200-500 $\mu \mathrm{g} / \mathrm{mL}$ of caffeic acid on rat tissue homogenates, reduce MDA formation in the presence of $\mathrm{Fe}^{2+}$ $\mathrm{H}_{2} \mathrm{O}_{2}$ with $\mathrm{IC}_{50}$ values $(38.15 \%),(37.50 \%)$ and $(55.40 \%)$, in heart, brain and liver rat tissue homogenates, respectively, indicating lower anti-lipid peroxidation activities of substrate. The results obtained with the tested metabolites significantly reduced malon-dialdehyde (MDA) formation in the presence ofFeSO $\mathrm{S}_{4}-\mathrm{H}_{2} \mathrm{O}_{2}$ in tissue homogenates indicating anti-lipid peroxidation activities. The inhibition percentages were in the range of $(23.65-48.12 \%)$, $(25.10-30.85 \%)$ and $(36.55-58.15 \%)$ in heart, brain and liver rat tissue homogenates, for metabolites (Caff-AM-1, Caff-AM-2 and Caff-AM-3),respectively, as recorded in (Table2).

It was interesting to note that the inhibition effects produced by the tested samples were more pronounced for liver tissue homogenates than heart and brain tissue homogenates, which could be especially beneficial in treatment of liver disease in cases with oxidative stress due to elevated levels of TBARS. Caff-AM-1 and Caff-AM-2, showed the highest inhibition activity against $\mathrm{FeSO}_{4} / \mathrm{H}_{2} \mathrm{O}_{2}$-stimulated lipid peroxidation in liver rat tissue homogenate (58.15 and $49.10 \%$ ), respectively, which was higher than both reference standards. Since DL- $\alpha$-tocopherol is thought to be associated with lipid-rich membranes; its anti-oxidative ability is highly effective in protecting membranes against lipid peroxidation, as peroxyl and alkoxylradicals. The data obtained from the present study indicates that the tested metabolites have an anti-lipid peroxidative character with similar reaction mechanisms to those of DL- $\alpha$-tocopherol. 
Table (2) Inhibition effect of caffeic acid, its metabolites and positive controls on $\mathrm{FeSO}_{4}$ $\mathrm{H}_{2} \mathrm{O}_{2}$ induced lipid peroxidation (MDA production)in rat tissue homogenate.

\begin{tabular}{|c|c|c|c|}
\hline \multirow{2}{*}{ Bioassay } & \multicolumn{3}{|c|}{ Inhibition effect $(\%)^{*}$} \\
\hline & Brain & Heart & Liver \\
\hline $\begin{array}{l}\text { Normal control without } \\
\mathrm{FeSO}_{4}-\mathrm{H}_{2} \mathrm{O}_{2}(\mathrm{MDA} \text { level) }\end{array}$ & $0.36 \pm 0.15$ & $0.22 \pm 0.10$ & $0.16 \pm 0.05$ \\
\hline $\begin{array}{c}\text { Induction by } \mathrm{FeSO}_{4}-\mathrm{H}_{2} \mathrm{O}_{2} \\
\text { (MDA level) }\end{array}$ & $0.72 \pm 1.30$ & $0.65 \pm 1.25$ & $0.44 \pm 1.15$ \\
\hline \multicolumn{4}{|c|}{ Substrates } \\
\hline Caffeic acid & $38.15 \pm 1.25$ & $37.50 \pm 1.25$ & $55.40 \pm 1.45$ \\
\hline \multicolumn{4}{|c|}{ Metabolites } \\
\hline Caff-AM-1 & $48.12 \pm 1.45$ & $30.85 \pm 1.20$ & $58.15 \pm 1.50$ \\
\hline Caff-AM-2 & $25.05 \pm 0.15$ & $29.40 \pm 1.20$ & $49.10 \pm 1.45$ \\
\hline Caff-AM-3 & $23.65 \pm 1.15$ & $25.10 \pm 1.20$ & $36.55 \pm 1.30$ \\
\hline \multicolumn{4}{|c|}{ Positive controls } \\
\hline DL, $\alpha$-tocopherol & $35.10 \pm 1.30$ & $38.70 \pm 1.30$ & $46.18 \pm 1.50$ \\
\hline BHT & $28.23 \pm 1.25$ & $22.05 \pm 1.20$ & 33.15 \pm 1.30 \\
\hline
\end{tabular}

$*$ Values are presented as mean \pm SE of 3-test sample observation. $P<0.05$ for all values.

\section{REFERENCES}

Bradford, M. M., (1976): "Protein determination method that involves the binding of Coomassie Brilliant Blue G-250 dye to proteins"Anal. Biochem. 72: 248-254.

Daoubi, M., Galán, R., Benharref, A., and Collado, I., (2005): "Screening study of lead compounds for natural product-based fungicides: antifungal activity and biotransformation of $6 \alpha, 7 \alpha$-Dihydroxy- $\beta$-himachaleneby Botrytis cinerea".,J. Agric. Food Chem., 53, 6673-6677.

De La Torre Boronat, M. C., and Lopez Tamames, E., (1997): "El Papel de Los Antioxidants", Alimentaria, 6, 19-27.

Defnoun, S., Labat, M., Ambrosio, M., Garcia, J. L., and Patel, B. K., (2000): "Papillobactercinnamivorans gen. Nov., a cinnamate-transforming bacterium from a shea cake digester”. Int. J. Syst. Evol. Microbiol. 50, 1221-28.

Faber, K., and Patel, R., (2000): "Chemical biotechnology: A happy marriage between chemistry and biotechnology: asymmetric synthesis via green chemistry". Curr.Opin. Biotechnol.,11, 517-519.

Gulçin, I., (2006): "Antioxidant activity of caffeic acid (3,4-dihydroxycinnamic acid". Toxicology, 217, 213-220. 
Halliwell, B. and Chirico, S. (1993): "Lipid Peroxidation: its mechanism, measurement, and significant." Am. J. Clin. Nutr. 57:715S-724S.

Hosny, M. and Rosazza, J. P. N. (2002): "Novel Oxidation of (+)-Catechin by Horseradish Peroxidase and Laccase", Journal of Agricultural and food chemistry, 50 (20): 5539-5545.

Hosny, M., and John P. N. Rosazza, J. P.N., (1999): "Microbial Hydroxylation and Methylation of Genistein By Streptomycetes". Journal of Natural Products. 62 (12), 1609-1612.

Hosoya, T., Yun, Y. S., and Kunugi, A., (2008): "Antioxidant phenylpropanoid glycosides from the leaves of Wasabia japonica". Phytochemistry,69, 827-832,

Ibrahim, A. Y., Mahmoud, K., and El-Hallouty, A. M., (2011): "Screening of Antioxidant and Cytotoxicity Activities of Some Plant Extracts fromEgyptian Flora", Journal of Applied Sciences Research, 7(7): 1246-1258.

Jeong Hun, K.,ByungJoo. L.,Jin Hyoung, K., Young Suk, Y., Kyu-Won, K., (2009): “Antiangiogenic effect of caffeic acid on retinal neovascularization" Vascular Pharmacology,51 (4), 262-267.

Jung, J. E., Kim, H. S., Lee, C. S., Park, D. H., Kim, Y. N., Lee, M. J., Lee, J. W., Park, J. W., Kim, M. S., and Chung, M. H., (2007): "Caffeic acid and its synthetic derivative CADPE suppress tumor angiogenesis by blocking STAT3-mediated VEGF expression in human renal carcinoma cells". Carcinogenesis. 28, 17801787.

Kuo, I. M., Yeh, D. B., and Pan, B. S., (1999): "Rapid Photometric Assay Evaluating Antioxidative Activity in Edible Plant Material" Journal of Agricultural and food chemistry, 47,3206-3209.

Leresche, J.,and Meyer, H., (2006): "Chemocatalysis and biocatalyst (biotransformation): some thoughts ofchemist and of a biotechnologist". Org. Process. Res. Dev., $10,572-580$.

Luna, H., (2004): “Aplicación de la biocatálisis a la preparaciónde intermediarios para la síntesis de fármacos”. J. Mex.Chem. Soc.,48, 211-219.

Maria-Joao, B., P. Nuno Palma, P., Almeida Lu, S., and Soares-da-Silva, P., (2007): "Catechol-O-methyltransferase and Its Inhibitors in Parkinson's Disease", CNS Drug Reviews, 13, (3), 352-379.

Mateos, R., Goya, L., and Bravo, L., (2006): "Uptake and Metabolism of Hydroxycinnamic Acids (Chlorogenic, Caffeic, and Ferulic Acids) by HepG2 Cells as a Model of the Human Liver". J. Agric. Food Chem., 54 (23), 8724-873.

Miles E. A., Zoubouli, P., Calder, P. C., and Phil, D., (2005): "Differential antiinflammatory effects of phenolic compounds from extra virgin olive identified in human whole blood cultures". Nutrition. 21, 389-394.

Nardini, M., Natella, F., Gentili, V., Di Felice, M., and Scaccini, C., (1997): "Effect of Caffeic Acid Dietary Supplementation on the Antioxidant Defense System in Rat: an in vivo Study". National Institute of Nutrition, 342 (1), 157-160.

Robert, C. B., John, B. S., and John, H., A., (1988): "Phenolic Compound Utilization by the Soft Rot Fungus Lecythophorahoffmannii”. Appl. Environ. Microbiol.,54 (7), 1882-1885. 
Rosazza, J., Haung, Z., Dostal, L., Volm, T. and Rosseau, B. (1995): "Biocatalytic transformation of ferulic acid, an abundant aromatic natural product". J. Ind.Microbiol. 15, 457-71.

Samejima, M., N., Tatarazako, T., Arakawa, Y., S., and Yoshimoto, T., (1987): "Metabolism of 3,4-dimethoxycinnamic acid and ferulic acid by mutant strains derived from Pseudomonas sp. TMY1009", MokuzaiGakkaishi., 33, 728-734.

Shimoni E., E., Ravid, U., and Shoham, Y., (2000): "Isolation of a Bacillus sp. capable of transforming isoeugenol to vanillin". J. Biotechnol., 78, 1-9.

Soo-Hyun, P., Yun-Beom, S., Seon-Mi, K., Jin-Koo, L., Jun-Sub, J., Hong-Won S., (2011): "The effect of caffeic acid on the antinociception and mechanisms in mouse" J. Korean Soc. App. Biological Chem.54, (2), 177-182.

Taha S., Hamida, M. A., Nadia M. S., Hosny, M., and Dalia A. M., (2011): "A New Flavonoid C-Glycoside from Celtisaustralis L. and Celtisoccidentalis L. Leaves and Potential Antioxidant and Cytotoxic Activities". Sci. Pharm.79, 963-975, Toshiki, F., Yuka, A., and Kuniki, K., "Biotechnological Production of Caffeic Acid by Bacterial Cytochrome P450 CYP199A2", Appl. Environ. Microbiol. 78 (17), 6087-6094.

Un-Ju, J., Mi-Kyung, L., Yong Bok, P., Seon-Min, J., and Myung-Sook C., (2006): "Antihyperglycemic and Antioxidant Properties of Caffeic Acid in db/db Mice" The Journal of Pharmacology and Experimental Therapeutics. 318 (2), 476-483.

Velasco, R., Gil, J., García, C., and Durango, D., (2010): "Production of 2-phenylethanol in the biotransformation of cinnamyl alcohol by the plant pathogenic fungus Colletotrichum acutatum". Vitae.,17, 272- 280.

Whiting, G. C., and Carr, J. G., (1959): "Metabolism of Cinnamic Acid and HydroxyCinnamic Acids by Lactobacillus pastorianus var. Quinicus" Nature, 184, $1427-1428$.

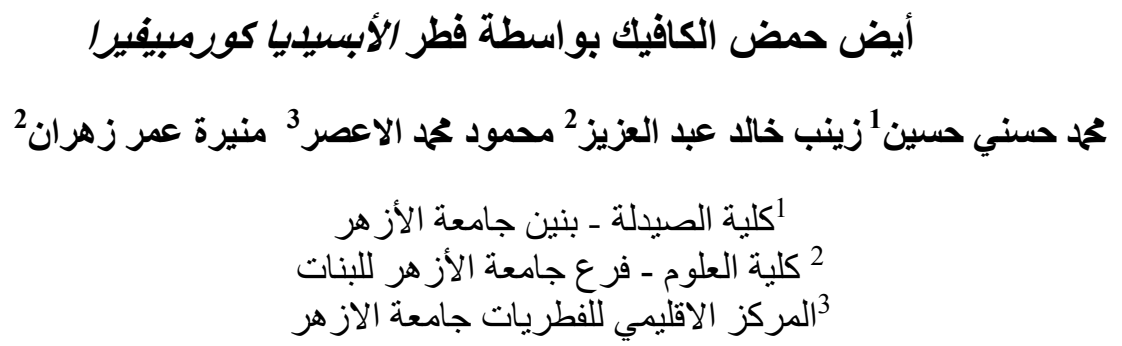

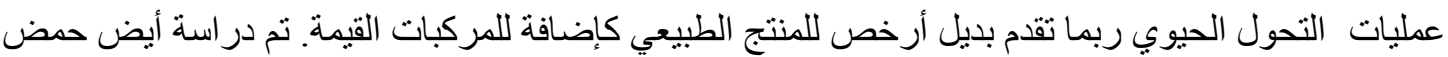

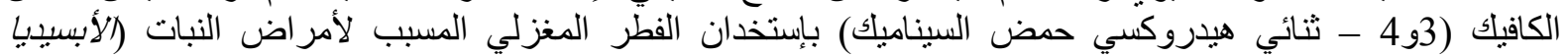

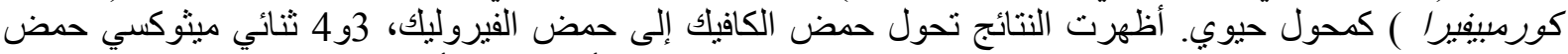

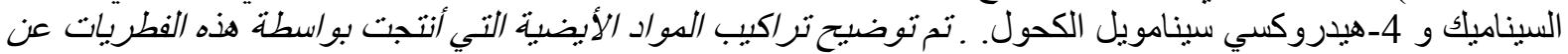

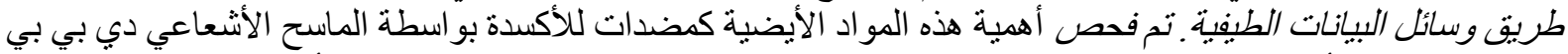

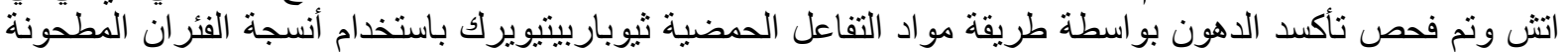


